\title{
IMPACT OF SYSTEMIC PGF2A PLUS INTRAUTERINE BENZATHINE CEPHAPIRIN COMBINATION IN TREATMENT OF CLINICALLY AND ULTRASONOGRAPHICALLY DIAGNOSED ENDOMETRITIS IN HOLSTEIN DAIRY COWS
}

\author{
KHALIL A.A.Y. ${ }^{1}$, HUSSEIN M.M. ${ }^{1}$, EL-AGAWANY A.A. ${ }^{1}$ and A.A. ZYADA ${ }^{2}$ \\ ${ }^{1}$ Theriogenology Dept., Fac. Vet. Med., Beni-Suef Univ. \\ ${ }^{2}$ Directorate of Vet. Med., General Authority of Vet. Service El-Fayoum/ Egypt
}

Received: 28 June 2017; Accepted: 31 July 2017

\begin{abstract}
The objectives of the present study were to validate transrectal ultrasonography (US) as a reliable diagnostic tool for endometritis, as well as to determine the efficiency of intrauterine infusion (IU) of benzathine cephapirin plus systemic PGF2 $\alpha$ as a treatment protocol of endometritis in Holstein dairy cows. 260 Holstein cows were included in this study. The affected cows were examined rectally and US. The cows were divided according to the diagnostic method and treatment protocol into 3 groups. Group1: rectally diagnosed and received systemic PGF2 $\alpha$. Group2: rectally diagnosed and received IU benzathine cephapirin plus systemic PGF2 $\alpha$. Group3: US diagnosed and received IU benzathine cephapirin plus systemic PGF2 $\alpha$. Good reproductive indices were recorded for cows examined US and treated with combination of IU benzathine cephapirin plus systemic PGF2 $\alpha$. A highly significant positive correlations were observed between days in milking (DIM) and most of tested reproductive indices. Meanwhile, Daily milk yield was negatively correlated with all tested reproductive indices. In conclusion, trans-rectal US could be used as a reliable method for early diagnosis of endometritis. In addition, using a combination of IU application of benzathine cephapirin plus systemic PGF2 $\alpha$ was superior treatment protocol in endometritis in comparison with PGF2 $\alpha$.
\end{abstract}

Key words: Benzathine cephapirin, dairy cows, endometritis, reproduction.

\section{INTRODUCTION}

A high level of reproductive efficiency requires each cow to be bred successfully, and calve with a calving interval that maximizes the milk output (Groenendaal et al., 2004). A healthy uterine environment is the key factor for optimal reproductive efficiency in dairy herds. The uterus is routinely contaminated with bacteria in the early postpartum period 2 to 3 weeks after calving (Sheldon and Dobson, 2004; Földi et al., 2006). A high proportion of infected cows, irrespective of treatment, have a spontaneous resolution of endometritis at 4-6 weeks postpartum through the natural immune defense mechanisms within the uterus (Sheldon et al., 2006). A high self-cure rate of subclinical endometritis (>90\%) at d 42 was observed (Priest et al., 2013). Uterine diseases can be classified as acute puerperal metritis, chronic clinical metritis,

Corresponding author: Dr. KHALIL A.A.Y.

E-mail address: yassyn999@yahoo.com

Present address: Theriologenology Dept. Fac. Vet. Med., BeniSuef Univ. clinical endometritis (recently called purulent vaginal discharge) and subclinical or cytological endometritis (Gilbert et al., 2005; Dubuc et al., 2010). Clinical endometritis in dairy cows is defined as mucopurulent or purulent vulvar discharge 21 days or more after parturition, and not accompanied by systemic signs (Sheldon et al., 2006). Subclinical endometritis is defined as the presence of $>18 \%$ polymorphonuclear cells in uterine cytology samples collected 21-33 days postpartum or $>10 \%$ polymorphonuclear in samples collected at days 34-47 postpartum (Sheldon et al., 2006; Sheldon et al., 2009). Cows with subclinical endometritis do not have uterine discharge. These diseases are highly prevalent in high producing dairy cows and have been associated with decreased reproductive performance, increased culling, economic losses, which ultimately affects herd profitability (Dubuc et al., 2010; 2011; Giuliodori et al., 2013; de Boer et al., 2014). Metritis affects about $20 \%$ of lactating dairy cows (Galvão $e t$ al., 2009; Huzzey et al., 2007). Clinical endometritis also affects about $20 \%$ of lactating dairy cows (Galvão et al., 2009; McDougall et al., 2007). Subclinical endometritis is the most prevalent of all uterine diseases; it affects $\sim 30 \%$ of lactating dairy cows, with the prevalence ranging from 11 to $>70 \%$ 
in some herds (Kasimanickam et al., 2004; Gilbert et al., 2005; Galvão et al., 2009). Many methods are used for the diagnosis of reproductive tract disease, including transrectal palpation, transrectal ultrasonography, uterine bacterial culture, the Metricheck (McDougall et al., 2007; Dubuc et al., 2010), vaginoscopy (Runciman et al., 2009), endometrial cytobrush (Kasimanickam et al., 2004; Gilbert et al., 2005; Dubuc et al., 2010), and endometrial leukocyte esterase (Cheong et al., 2012; Couto et al., 2013). Although, endometrial biopsy is the most definitive diagnostic tool for endometritis in the mare it has been recognized as being too time consuming and expensive practice in cattle (Gilbert et al., 2005; Sheldon et al., 2006). Transrectal ultrasonography has been used to detect intrauterine fluid accumulation associated with endometritis and offers the advantage of an immediate diagnosis (Kasimanickam et al., 2004; Drillich et al., 2004). The treatment of bacterial endometritis with an intrauterine infusion of antibacterial agents and antibiotics before or after insemination results in varying degrees of success (Kasimanickam et al., 2005; Ahmadi and Dehghan, 2007; Runciman et al., 2008). Intrauterine cephapirin infusion has been shown by multiple studies to improve reproductive performance of dairy cows with clinical and subclinical endometritis (Kasimanickam et al., 2005; Denis-Robichaud and Dubuc, 2015). Another treatment strategy is the use of systemic PGF $2 \alpha$. The benefit from PGF $2 \alpha$ administration is believed to arise from induction of estrus in cows having a PGF $2 \alpha$-responsive corpus luteum; physical expulsion of bacterial contaminants and inflammatory products as well as a possible improvement in the uterine defenses under low progesterone (Kasimanickam et al., 2005). PGF2 $\alpha$ also appears to have proinflammatory actions that might enhance neutrophil function (Lewis, 2004). Effectiveness of PGF2 $\alpha$ is dependent on time postpartum at treatment, severity of inflammation in the uterus, and presence of a CL (Lefebvre and Stock, 2012). Nevertheless, later studies found no beneficial effect of PGF2 $\alpha$ alone for treatment of subclinical endometritis (Galvão et al., 2009; Dubuc et al., 2011), therefore, the combination of intrauterine cephapirin and systemic PGF2 $\alpha$ may be an efficacious method to treat subclinical endometritis. No available studies utilizing transrectal ultrasonography to quantify either endometrial thickness or intrauterine luminal fluid volume were found. Further studies are needed to evaluate and refine these techniques so that appropriate diagnostic protocols may be recommended to veterinary practitioners. Therefore, the objectives of the present study were to validate US as a reliable diagnostic tool in early detection of clinical endometritis, as well as to determine the effects of combination of intrauterine (IU) infusion of benzathine cephapirin plus intramuscular PGF2 $\alpha$ as a treatment protocol of endometritis in Holstein dairy cows.

\section{MATERIALS AND METHODS}

\section{Animals:}

The present study was carried out on 260 Holstein cows distributed in eight commercial dairy farms located in six Egyptian provinces (El-Fayoum, Ismailia, Matrouh, Beni-Suef, El-Sharqiah and ElDaqahliah) with similar management and feeding systems. The cows included in this study had a previous normal breeding history (i.e. no repeat breeding syndrome). The herds ranged in size from 97 to 1700 milking cows with different parities. The cows were housed in an open yard system and fed a total mixed ration (TMR) according to Nutrient Requirements of Dairy Cattle published by the National Research Council (NRC, 2001). A permanent sources of fresh drinking water are available ad-libs in all farms. The cows were routinely vaccinated against all infectious diseases according to programs of vaccination. All cows appeared healthy and had body condition score (BCS) around 3 (scale 1 to 5) during the entire study. The cows were between 21 and 210 DIM at the time of initial examination. Data including DIM, parity, calving history and incidence of periparturient disorders were recorded.

\section{Chemicals (Drugs)}

Metricure $^{\circledR}$ intra-uterine oily suspension of $500 \mathrm{mg}$ benzathine cephapirin packaged in $19 \mathrm{~g}$ syringes and Estrumate $^{\circledR}$ (MSD) (each ml contains $263 \mu \mathrm{g}$ of cloprostenol sodium salt, equivalent to $250 \mu \mathrm{g}$ of cloprostenol) IM injectable solution were used in the present study. The Metricure ${ }^{\circledR}$ was injected intrauterine 3-5 days after estrus detection while Estrumate ${ }^{\circledR}$ was injected at the time of diagnosis. Each cow received only one injection from each drug according to the treatment protocol.

\section{Ultrasound Scanner}

A real time B-mode (Brightness modality) linear array ultra sound scanner (Mindray DP-2200Vet China) was used. The scanner was provided with a transrectal linear transducer (3.5-10 MHZ) for transrectal scanning. USB device was used to store the frozen images. Ultrasonic gel was used to cover the short distance between the transducer scan head and the rectal wall.

\section{Diagnosis of Endometritis}

Endometritis was diagnosed through ultrasonographic examination in 135 cows depending on the uterine fluid content and echogenicity of endometrial layer. Endometritis was diagnosed through manual palpation per rectum in 125 cows depending on the size, contractility of the uterus, nature vaginal discharge as shown in figure 1. Figure 2 show the ultrasonographic pictures of same cow before and after treatment till became pregnant. 

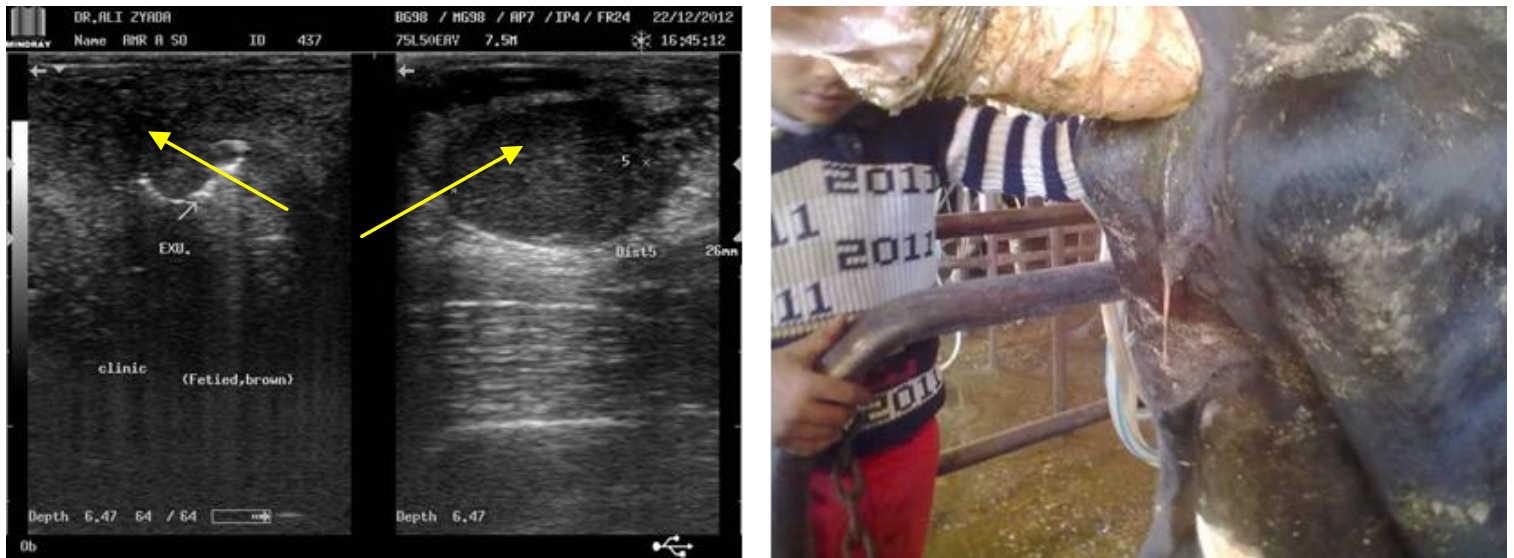

Figure (1) Endometritis, with CL on corresponding ovary (Diameter $26 \mathrm{~mm}$ ), photo on the Right for the same cow show vaginal mucopurulent discharge.
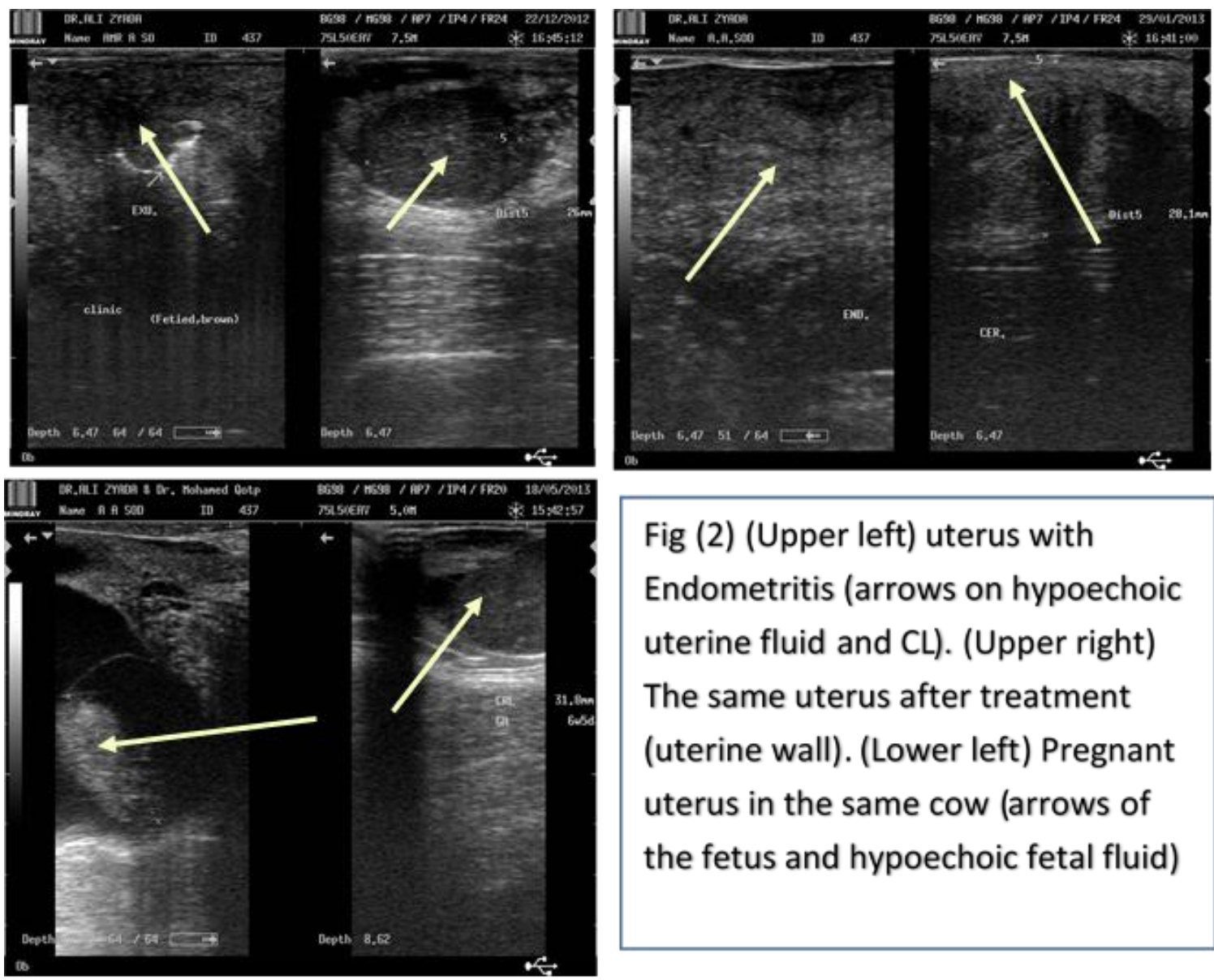

Fig (2) (Upper left) uterus with Endometritis (arrows on hypoechoic uterine fluid and $\mathrm{CL}$ ). (Upper right) The same uterus after treatment (uterine wall). (Lower left) Pregnant uterus in the same cow (arrows of the fetus and hypoechoic fetal fluid)

\section{Experimental design}

The cows were divided according to DIM into $<60$ DIM and $\geq 60$ DIM., according to parity into primiparous and pleuriparous, according to average daily milk yield into $\leq$ and $>$ the average corresponding to the farm average $(24.0 \mathrm{~kg})$. According to the method of diagnosis and treatment protocol, the cows were divided into 3 groups:

5.1. Group $\mathbf{1}(\mathbf{N}=\mathbf{5 1})$ : This group included cows that were diagnosed rectally and received only

synthetic PGF2 $\alpha, \quad(500 \mu \mathrm{g}$ cloprostenol), intramuscular (IM) at time of diagnosis.

5.2. Group2 ( $\mathbf{N = 7 4 ) : ~ T h i s ~ g r o u p ~ i n c l u d e d ~ c o w s ~ t h a t ~}$ were diagnosed rectally and received synthetic PGF2 $\alpha \quad(500 \mu \mathrm{g}$ cloprostenol) IM at time of diagnosis plus $500 \mathrm{mg}$ benzhine cephapirin intrauterine, 3-5 days after estrus detection.

5.3. Group 3 (N=135): This group included cows that were diagnosed US and received $500 \mu \mathrm{g}$ 
cloprostenol IM at time of diagnosis plus 500 $\mathrm{mg}$ benzathine cephapirin intra-uterine 3-5 days after estrus detection.

\section{Evaluation of the reproductive response to the treatment of endometritis.}

The treatment response in each experiment was determined using certain fertility indices such as: interval from treatment to $1^{\text {st }}$ estrus, interval from treatment to $1^{\text {st }}$ service, interval from treatment to $1^{\text {st }}$ conception, days open and services per conception.

\section{Statistical analysis and data processing}

Statistical analyses were performed using SPSS (2013). The success of the therapy was evaluated by determination of some selected reproductive indices including the intervals from the treatment to: the $1^{\text {st }}$ estrus, the $1^{\text {st }}$ insemination, the conception, and both the number of services per conception and days open. Pearson's correlation coefficients were used to compare results between variables. All data are presented as means \pm SEM. The results were found to be significant when $\mathrm{P}<0.05$.

\section{RESULTS}

1. Descriptive statistics of cows suffered from endometritis (Table.1).

The cows included in this study were at about 2.5 parity, and had about 3.0 degree body condition score (BCS). DIM was $68.3 \pm 2.1 \mathrm{~d}$. In average with a wide range from $42 \mathrm{~d}$.to $262 \mathrm{~d}$. The average daily milk was $24 \mathrm{~kg}$. The interval from treatment to $1^{\text {st }}$ estrus was $31.4 \mathrm{~d}$. Nearly the same trend was observed for the interval from treatment to the $1^{\text {st }}$ insemination (38.9d). The interval from treatment to conception averaged $85.5 \mathrm{~d}$. The mean value of open days was 134.4d. Cows included in our study required about 2.5 Services per conception (S/C).

Table 1: Descriptive statistics of dairy cows suffered from endometritis.

\begin{tabular}{cccc}
\hline Item & Min. & Max. & Mean \pm SE \\
\hline Parity (number) & 1.0 & 10.0 & $2.5 \pm 0.1$ \\
\hline DIM at treatment (days) & 42.0 & 262.0 & $68.3 \pm 2.1$ \\
\hline Daily milk yield at treatment (kg) & 10.4 & 41.4 & $24.0 \pm 0.4$ \\
\hline BCS at treatment (unit) & 2.0 & 4.0 & $3.0 \pm 0.04$ \\
\hline Treatment to 1st estrus (days) & 1.0 & 151.0 & $31.4 \pm 1.9$ \\
\hline Treatment to 1st AI (days) & 1.0 & 188.0 & $38.9 \pm 2.2$ \\
\hline Treatment to conception (days) & 4.0 & 280.0 & $85.5 \pm 5.5$ \\
\hline Days open (days) & 57.0 & 284.0 & $134.4 \pm 5.1$ \\
\hline Services per conception (S/C) & 1.0 & 6.0 & $2.5 \pm 0.1$ \\
\hline
\end{tabular}

Min. = Minimum, Max. = Maximum and SE $=$ Standard Error.

2. Effect of diagnosis and treatment protocol on the reproductive response in cows affected with endometritis

Cows examined with US recorded significant $(\mathrm{P}<0.05)$ short treatment to $1^{\text {st }}$ estrus $(10.3 \pm 0.7 \mathrm{~d}$. $)$, short treatment to $1^{\text {st }}$ AI $(17.9 \pm 1.4 \mathrm{~d}$.), short treatment to conception $(36.7 \pm 2.6 \mathrm{~d}$.) intervals, short days open (104.1 \pm 4.7 d.) and less $S / C(2.0 \pm 0.1)$ compared to that recorded for the rectally diagnosed cows despite the same treatment protocol. Concerning the treatment protocol, the results of the current study revealed that the fertility indices in cows received local intrauterine cephapirin plus systemic PGF2 $\alpha$ were superior to that recorded for cows received only systemic PGF $2 \alpha$ as shown in table 2

Table 2: Effect of diagnosis and treatment protocol on the reproductive response in cows affected with endometritis

\begin{tabular}{|c|c|c|c|}
\hline Treatment Protocol & $\begin{array}{c}\text { PGF2 } \alpha \mathrm{IM} \\
\text { (rectally diag., } \mathrm{N}=51 \text { ) }\end{array}$ & $\begin{array}{c}\text { PGF2 } \alpha \text { IM } \\
+ \text { IU cephapirin (rectally } \\
\text { diag. } \mathrm{N}=74 \text { ) }\end{array}$ & $\begin{array}{c}\text { PGF2 } \alpha \text { IM } \\
+ \text { IU cephapirin } \\
\text { (US diag. } \mathrm{N}=135\end{array}$ \\
\hline Treatment to $1^{\text {st }}$ estrus (days) & $60.3 \pm 4.5^{b}$ & $52.2 \pm 3.3^{\mathrm{b}}$ & $10.3 \pm 0.7^{\mathrm{a}}$ \\
\hline Treatment to $1^{\text {st }}$ AI (days) & $74.7 \pm 5.6^{\mathrm{c}}$ & $54.9 \pm 3.5^{b}$ & $17.9 \pm 1.4^{\mathrm{a}}$ \\
\hline Treatment to conception (days) & $155.3 \pm 11.6^{b}$ & $135.4 \pm 7.9^{b}$ & $36.7 \pm 2.6^{\mathrm{a}}$ \\
\hline Days open (days) & $172.6 \pm 11.6^{b}$ & $164.7 \pm 9.8^{b}$ & $104.1 \pm 4.7^{\mathrm{a}}$ \\
\hline $\mathrm{S} / \mathrm{C}$ (unit) & $3.1 \pm 0.3^{\mathrm{b}}$ & $3.2 \pm 0.2^{\mathrm{b}}$ & $2.0 \pm 0.1^{\mathrm{a}}$ \\
\hline
\end{tabular}

Values are expressed as Mean $\pm \mathrm{SE}, \mathrm{S} / \mathrm{C}=$ Number of services per conception, IU = Intrauterine; US = ultrasonography examined. Within the same row, means with different superscript letters are significantly different at $\mathrm{P}<0.05$. 
3. Pearson's correlation coefficients among factors influencing the reproductive indices after treatment of cows suffering from endometritis In the present study, weak non-significant negative correlations were observed among parity and all selected reproductive indices. Significant positive correlations were observed among DIM and intervals to $1^{\text {st }}$ estrus $(\mathrm{p}<0.5,0.31)$, to $1^{\text {st }} \mathrm{AI}(\mathrm{p}<0.5,0.30)$ and days open $(p<0.5,0.41)$. Daily milk yield showed strong significant negative correlations with treatment intervals to $1^{\text {st }}$ estrus $(\mathrm{p}<0.5,-0.40)$, to $1^{\text {st }}$ service $(\mathrm{p}<0.5,-.033)$, to conception $(\mathrm{p}<0.5,-0.58)$, days open $(\mathrm{p}<0.5,-0.57)$ and $\mathrm{S} / \mathrm{C}(\mathrm{p}<0.5,-0.27)$ as shown in Table 3.

Table 3: Pearson's correlation coefficients among factors influencing the reproductive indices after treatment of cows suffering from endometritis

\begin{tabular}{|c|c|c|c|c|c|}
\hline $\begin{array}{l}\text { Indices } \\
\text { Factors }\end{array}$ & $\begin{array}{c}\text { Treatment to } 1^{\text {st }} \\
\text { estrus }\end{array}$ & $\begin{array}{c}\text { Treatment to } 1^{\text {st }} \\
\text { AI }\end{array}$ & $\begin{array}{c}\text { Treatment to } \\
\text { conception }\end{array}$ & Days open & $\mathrm{S} / \mathrm{C}$ \\
\hline Parity & -0.08 & -0.11 & -0.14 & -0.03 & -0.02 \\
\hline DIM at treatment & $0.31 * *$ & $0.30 * *$ & 0.09 & $0.41 * *$ & -0.12 \\
\hline Daily milk at treatment & $-0.40 * *$ & $-0.33 * *$ & $-0.58 * *$ & $-0.57 * *$ & $-0.27 * *$ \\
\hline
\end{tabular}

$\mathrm{S} / \mathrm{C}=$ Number of services per conception, $* *$ Significant correlation at $\mathrm{P}<0.01$

3.4. Effect of DIM on some reproductive indices after treatment of endometritis in dairy cows

The results of the present study revealed significant positive correlations among DIM and intervals to $1^{\text {st }}$ estrus (0.31), $1^{\text {st }}$ AI (0.30) and days open (0.41) as shown in table 3 . In details our study showed that, the best fertility indices were recorded for endometritis positive cows detected and treated early before 60 days in milk when compared to cows detected and treated after 60 days in milk. Despite the same diagnostic and treatment protocols, significant lower intervals to $1^{\text {st }}$ estrus $\left(9.34 \pm 0.7 \mathrm{~d}\right.$.), to $1^{\text {st }}$ AI

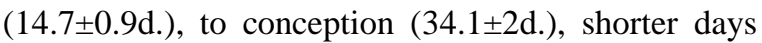

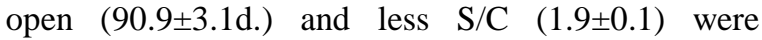
recorded for cows experienced endometritis before 60 DIM (Table 4).

Table 4: Effect of DIM on some reproductive indices after treatment of endometritis in dairy cows

\begin{tabular}{|c|c|c|c|c|c|c|}
\hline DIM & & $<60$ DIM & & & $\geq 60$ DIN & \\
\hline Indices & PGF2 $\alpha$ & $\begin{array}{c}\text { PGF2 } \alpha+\text { IU } \\
\text { cephapirin }\end{array}$ & $\begin{array}{c}\text { PGF2 } \alpha+\text { IU } \\
\text { cephapirin (US) }\end{array}$ & PGF2 $\alpha$ & $\begin{array}{c}\text { PGF2 } \alpha+\text { IU } \\
\text { cephapirin }\end{array}$ & $\begin{array}{l}\text { PGF } 2 \alpha+\text { IU } \\
\text { cephapirin (US) }\end{array}$ \\
\hline $\begin{array}{c}\text { Treatment to } 1^{\text {st }} \\
\text { estrus }\end{array}$ & $67.2 \pm 11.2^{\mathrm{c}}$ & $41.0 \pm 2.4^{\mathrm{b}}$ & $9.34 \pm 0.7^{\mathrm{a}}$ & $57.5 \pm 4.4^{\mathrm{c}}$ & $63.36 \pm 5.6^{c}$ & $12.62 \pm 1.6^{\mathrm{a}}$ \\
\hline $\begin{array}{c}\text { Treatment to } 1^{\text {st }} \\
\text { service }\end{array}$ & $67.2 \pm 11.2^{\mathrm{c}}$ & $46.3 \pm 2.7^{\mathrm{c}}$ & $14.7 \pm 0.9^{\mathrm{a}}$ & $77.83 \pm 6.5^{\mathrm{c}}$ & $67.33 \pm 6.7^{\mathrm{c}}$ & $25.77 \pm 3.9^{b}$ \\
\hline $\begin{array}{c}\text { Treatment to } \\
\text { conception }\end{array}$ & $178 \pm 26.8^{c}$ & $132.9 \pm 7.3^{b}$ & $34.1 \pm 2.9^{\mathrm{a}}$ & $142.29 \pm 9.3^{b c}$ & $148 \pm 32.2^{\mathrm{bc}}$ & $44.43 \pm 4.9^{\mathrm{a}}$ \\
\hline Days open & $191.5 \pm 26.9^{b c}$ & $153.4 \pm 10.4^{\mathrm{b}}$ & $90.9 \pm 3.1^{\mathrm{a}}$ & $161.86 \pm 9.8^{b c}$ & $221.5 \pm 11.4^{\mathrm{c}}$ & $140 \pm 12.7^{\mathrm{b}}$ \\
\hline $\mathrm{S} / \mathrm{C}$ & $3.0 \pm 0.5^{\mathrm{b}}$ & $3.4 \pm 0.2^{\mathrm{b}}$ & $1.9 \pm 0.1^{\mathrm{a}}$ & $3.14 \pm 0.33^{\mathrm{b}}$ & $2.0 \pm 0.0^{\mathrm{ab}}$ & $2.29 \pm 0.2^{\mathrm{ab}}$ \\
\hline
\end{tabular}

Values are expressed as Mean $\pm \mathrm{SE}, \mathrm{S} / \mathrm{C}=$ Number of services per conception. Within the same row, means with different superscript letters differ significantly at $\mathrm{P}<0.05 .3 .5$. Effect of parity on reproductive response to treatment of endometritis

\subsection{Effect of parity on some reproductive indices} after treatment of endometritis in dairy cows

The best fertility results were detected in primiparous cows, as short intervals to $1^{\text {st }}$ estrus $\left(6.9 \pm 0.7 \mathrm{~d}\right.$.), to $1^{\text {st }}$
AI $(10.8 \pm 1.6 \mathrm{~d}$.), to conception (35.9 $\pm 5.9 \mathrm{~d}$.), short days open $(96.3 \pm 6.6 \mathrm{~d}$.) and less S/C $(2.0 \pm 0.17)$ compared to that recorded for pleuriparous cows (Table 5). 
Table 5: Effect of parity on some reproductive indices after treatment of endometritis in dairy cows

\begin{tabular}{|c|c|c|c|c|c|c|}
\hline Parity & & imiparous cow & & & euriparous cov & \\
\hline Indices & PGF $2 \alpha$ & $\begin{array}{l}\text { PGF } 2 \alpha+\mathrm{IU} \\
\text { cephapirin }\end{array}$ & $\begin{array}{c}\text { PGF } 2 \alpha+\mathrm{IU} \\
\text { cephapirin } \\
\text { (US) }\end{array}$ & PGF $2 \alpha$ & $\begin{array}{l}\text { PGF } 2 \alpha+\mathrm{IU} \\
\text { cephapirin }\end{array}$ & $\begin{array}{l}\text { PGF2 } \alpha+I U \\
\text { cephapirin } \\
\text { (US) }\end{array}$ \\
\hline $\begin{array}{c}\text { Treatment to } 1^{\text {st }} \\
\text { estrus }\end{array}$ & $76.3 \pm 8.2^{c}$ & $66.2 \pm 9.9^{\mathrm{c}}$ & $6.9 \pm 0.7^{\mathrm{a}}$ & $49.2 \pm 4.1^{\mathrm{c}}$ & $46.9 \pm 2.7^{\mathrm{c}}$ & $11.3 \pm 0.8^{\mathrm{b}}$ \\
\hline $\begin{array}{c}\text { Treatment to } 1^{\text {st }} \\
\text { AI }\end{array}$ & $99.6 \pm 10.9^{c}$ & $68.8 \pm 11.9^{b}$ & $10.8 \pm 1.6^{\mathrm{a}}$ & $57.3 \pm 3.2^{b}$ & $50.6 \pm 2.5^{\mathrm{b}}$ & $19.9 \pm 1.6^{\mathrm{a}}$ \\
\hline $\begin{array}{c}\text { Treatment to } \\
\text { conception }\end{array}$ & $183 \pm 17.2^{c}$ & $158.5 b \pm 27.5^{c}$ & $35.9 \pm 5.9^{\mathrm{a}}$ & $122 \pm 9.9^{b}$ & $130.8 \pm 7.7^{b}$ & $36.9 \pm 2.8^{\mathrm{a}}$ \\
\hline Days open & $199 \pm 16.8^{b}$ & $179.5 \pm 30.2^{b}$ & $96.3 \pm 6.6^{\mathrm{a}}$ & $141 \pm 11.6^{b}$ & $161.8 \pm 10.3^{b}$ & $107.05 \pm 6.0^{\mathrm{a}}$ \\
\hline $\mathrm{S} / \mathrm{C}$ & $3.17 \pm 0.4^{\mathrm{b}}$ & $2.0 \pm 0.0^{\mathrm{a}}$ & $2.0 \pm 0.17^{\mathrm{a}}$ & $3.0 \pm 0.38^{\mathrm{b}}$ & $3.4 \pm 0.15^{\mathrm{b}}$ & $2.0 \pm 0.14^{\mathrm{a}}$ \\
\hline
\end{tabular}

Values are expressed as Means, $\mathrm{S} / \mathrm{C}=$ Number of services per conception. Within the same row, means with different superscript letters differ significantly at $\mathrm{P}<0.05$.

3.6. Effect of average daily milk yield on some reproductive indices after treatment of endometritis in dairy cows

The data of the current study revealed that cows producing more than the average daily milk recorded the shorter treatment to $1^{\text {st }}$ estrus $(10.06 \pm 0.8 \mathrm{~d}$.), shorter treatment to $1^{\text {st }}$ AI $(17.2 \pm 1.8 \mathrm{~d}$.), shorter treatment to conception (35.8 $\pm 2.8 \mathrm{~d}$.) intervals, lower

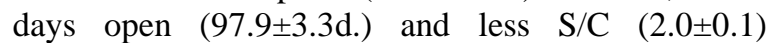
compared to those recorded for cows that yields less than the average daily milk as shown in table 6 .

Table 6: Effect of average daily milk yield on some reproductive indices after treatment of endometritis in dairy cows

\begin{tabular}{|c|c|c|c|c|c|c|}
\hline Milk yield & & $\leq$ average yield & & & $>$ average yield & \\
\hline Indices & PGF $2 \alpha$ & $\begin{array}{c}\text { PGF2 } \alpha+\text { IU } \\
\text { cephapirin }\end{array}$ & $\begin{array}{c}\text { PGF2 } \alpha+\text { IU } \\
\text { cephapirin (US) }\end{array}$ & PGF $2 \alpha$ & $\begin{array}{r}\text { PGF2 } \alpha+\text { IU } \\
\text { cephapirin }\end{array}$ & $\begin{array}{c}\text { PGF } 2 \alpha+\text { IU } \\
\text { cephapirin } \\
\text { (US) }\end{array}$ \\
\hline $\begin{array}{c}\text { Treatment to } 1^{\text {st }} \\
\text { estrus }\end{array}$ & $68 \pm 6.6 c$ & $46.9 \pm 3.3 b$ & $10.9 \pm 1.5 \mathrm{a}$ & $49.4 \pm 4.9 \mathrm{~b}$ & $85.3 \pm 4.7 \mathrm{c}$ & $10.06 \pm 0.8 \mathrm{a}$ \\
\hline Treatment to $1^{\text {st }} \mathrm{AI}$ & $86.4 \pm 8.6 c$ & $48.9 \pm 4.0 \mathrm{~b}$ & $36 \pm 19.8 \mathrm{ab}$ & $58 \pm 4.0 \mathrm{~b}$ & $74 \pm 4.6 \mathrm{bc}$ & $17.2 \pm 1.8 \mathrm{a}$ \\
\hline $\begin{array}{c}\text { Treatment to } \\
\text { conception }\end{array}$ & $181.2 \pm 17.4 \mathrm{~d}$ & $141.9 \pm 9.0 \mathrm{c}$ & $40.6 \pm 5.6 a$ & $124.2 \pm 10.2 \mathrm{c}$ & $103 \pm 0.0 b$ & $35.8 \pm 2.8 \mathrm{a}$ \\
\hline Days open & $198.3 \pm 16.9 \mathrm{~d}$ & $176.3 \pm 10.6 \mathrm{~cd}$ & $130.4 \pm 19.7 \mathrm{ab}$ & $141.8 \pm 11.7 \mathrm{bc}$ & $107 \pm 0.0 \mathrm{ab}$ & $97.9 \pm 3.3 \mathrm{a}$ \\
\hline $\mathrm{S} / \mathrm{C}$ & $3.0 \pm 0.4 \mathrm{c}$ & $3.2 \pm 0.2 \mathrm{c}$ & $2.0 \pm 0.3 \mathrm{ab}$ & $3.2 \pm 0.4 \mathrm{c}$ & $3.0 \pm 0.0 \mathrm{bc}$ & $2.0 \pm 0.1 \mathrm{a}$ \\
\hline
\end{tabular}

Values are expressed as Mean \pm SE, within the same row, means with different letters differ significantly at $\mathrm{P}<0.05$.

\subsection{Effect of the ultrasonographic picture of the uterus on some reproductive indices after treatment of endometritis in dairy cows.}

Regarding the ultrasonographic picture of the uterus of affected cows, the results of the current study revealed that, cows with Hyperechogenic endometrium recorded significant $(\mathrm{p}<0.05)$ shorter days to $1^{\text {st }}$ estrus interval $(8.4 \pm 0.7 \mathrm{~d}$.) compared to cows showed intra uterine luminal fluid (11.9 $\pm 1.1 \mathrm{~d}$.), although the rest of the selected fertility indices were not significantly affected (Table 7). 
Table 7: Effect of the ultrasonographic picture of the uterus on some reproductive indices after treatment of endometritis in dairy cows.

\begin{tabular}{cccc}
\hline Indices & US & $\begin{array}{c}\text { Hyper echogenic endometrium } \\
\text { fluid }\end{array}$ & $\begin{array}{c}\text { P value } \\
\text { Treatment to } 1^{\text {st }} \text { estrus Interval }\end{array}$ \\
\hline Treatment to $1^{\text {st }} \mathrm{AI}$ & $8.4 \pm 0.7 \mathrm{a}$ & $11.9 \pm 1.1 \mathrm{~b}$ & $<0.01$ \\
\hline Treatment to conception & $19.4 \pm 2.6$ & $16.6 \pm 1.2$ & 0.31 \\
\hline Days open & $34.6 \pm 3.7$ & $38.5 \pm 3.6$ & 0.46 \\
\hline S/C & $101.7 \pm 4.3$ & $104.3 \pm 7.9$ & 0.78 \\
\hline
\end{tabular}

Means with different letters differ significantly at $\mathrm{P}<0.01$.

\section{DISCUSSION}

The objectives of the present study were to evaluate the efficiency of IU infusion of benzathine cephapirin (Metricure $^{\circledR}$ ) plus IM administration of PGE2 $\alpha$ (Estrumate $^{\circledR}$ ) as a treatment protocol of endometritis, also to validate the use of transrectal US as a diagnostic tool for endometritis in dairy cows. A high prevalence of uterine disease such as endometritis dramatically impairs the reproductive performance of high yielding dairy cows due to persistent bacterial infection, which leads to inflammation and damage to the endometrium thereby, prolonging uterine involution and impairing fertility (Kasimanickam et al., 2004). Regarding the diagnostic method, our results showed that, cows examined US recorded a significant $(\mathrm{P}<0.05)$ short intervals to $1^{\text {st }}$ estrus (10.3d.), to $1^{\text {st }}$ AI (17.9d.), to conception (36.7d.), short days open (104.15d.) and less S/C (2.0 \pm 0.1$)$ compared with that recorded for the rectally examined cows despite the same treatment protocol (Table 2). The low fertility results obtained in the present study after using rectal palpation may be attributed to the fact that palpation per rectum is a challenge because uterine size and palpable quality of the uterine content is subjective and strongly depends on the stage of the postpartum period. Our results came in agreement with that reported by others (Földi et al., 2006; Palmer, 2008) who found that, diagnosis of clinical endometritis using rectal palpation is subjective, not effective and prone to error as it lacks standardization. In the same manner, it had been reported that, transrectal palpation to identify the presence of a CL is imperfect (Shephard, 2005; Bicalho et al., 2008), but generally has a high specificity and is a "useful tool" that is widely used in veterinary practice. The good fertility results obtained in this study after using US as a diagnostic tool were corresponded to others (Kasimanickam et al., 2004). In the present study, the US detection of intrauterine fluid was the unique feature for diagnosis of endometritis and this was supported by Kasimanickam et al. (2004) who considered the presence of any US detectable uterine fluid as evidence of subclinical endometritis. In addition, use of US might increase the accuracy of identification of a CL (Shephard, 2005). On the contrary, Ghasemi (2011) reported that US measurements of both cervical diameter and endometrial thickness is not useful for detecting cows with endometritis. Concerning the influence of treatment protocol on the reproductive response, the results of the current study revealed that the fertility results in cows received local IU cephapirin plus systemic PGF2 $\alpha$ were superior to that recorded for cows received only systemic PGF2 $\alpha$ in spite the same diagnostic method (Table 2). This may be attributed to the theory that, postpartum cows with uterine luminal fluid accumulation might benefit from prostaglandin treatment beside more than one treatment with IU cephapirin is necessary to overcome the effects of fluid accumulation because it is likely to induce estrus, which in effect softens and opens the cervix and increases uterine contractility. In line with our results, previous authors (Kasimanickam et al., 2005; Drillich et al., 2005; Runciman et al., 2008 \& 2009) reported that treatment of cows suffered from clinical or subclinical postpartum endometritis with IU cephapirin resulted in significant improvement of the reproductive performance of these cows. Moreover, Denis-Robichaud and Dubuc (2015) reported that, an intrauterine infusion of cephapirin improved firstservice pregnancy risk in cows with postpartum reproductive tract disease and this effect was influenced by postpartum anovulation status. Furthermore, it had been recommended that, intrauterine infusions with cephapirin as well as the administration of PGF $2 \alpha$ is effective in the treatment of subclinical endometritis (Kasimanickam et al., 2005). Benzathine cephapirin is a very effective treatment for endometritis in the postpartum dairy cow modified at risk (Runciman et al., 2008; Ghasemi, 2011). Moreover, benzathine cephapirin has been reported to be the most effective antibiotic for intrauterine infusion in lactating dairy cows and has been shown to be more effective than PGF $2 \alpha$ treatment for subclinical endometritis (Kasimanickam et al., 2005). In line with our results, LeBlanc (2008) 
showed that using cephapirin in cows 27 and 33 days postpartum resulted in a $60 \%$ higher likelihood of those cows becoming pregnant and a $29 \%$ reduction in time to pregnancy compared to their untreated herd mates. On the contrary to our results, intrauterine infusions by cephapirin had nonsignificant effects on subsequent reproductive performance as cited by Gümen et al. (2012) who concluded that, intrauterine cephapirin administration was not found to be useful for the treatment of potential subclinical endometritis in repeat breeder dairy cows. Furthermore, Gilbert et al. (2005) and Lincke et al. (2005) did not confirm the efficiency of this treatment. Therefore, using an appropriately enough combination of systemic PGF2 $\alpha$ and an IU infusion with benzathine cephapirin in cows diagnosed with endometritis and having a palpable CL might improve reproductive performance. Regarding the efficacy of PGF $2 \alpha$ alone as a treatment tool of endometritis, a poor therapy result was observed in the current study and may be attributed to the theory that, treating cows early in the postpartum period, there may have been a bias against a significant beneficial effect of treatment with PGF $2 \alpha$, because a majority of cows did not have a sensitive CL on their ovaries, and thus ineffective prostaglandin treatment. These results were supported by Hendricks et al. (2006), who reported that treatment with PGF2 $\alpha$ analogues has no remedy effect on clinical endometritis. Moreover, Dubuc et al. (2011) reported that, administration of PGF2 $\alpha$ at both 5 and 7 weeks postpartum did not mitigate the effects of endometritis on reproductive performance. On the other hand, some researchers suggested that the use of PGF $2 \alpha$ for the treatment of endometritis is efficient not only by induction of myometrial contractions and estrus (Weems et al., 2006), but also by regulation of inflammatory responses in the endometrium. It has been demonstrated that bacterial endotoxin lipopolysaccharide, expressed by uterine pathogens such as E. coli switch the endometrial epithelial secretion of prostaglandins from the $\mathrm{F}$ to the prostaglandin E series. This results in prolonged luteal phases and modulation of endocrine functions that are essential for reproduction (Herath et al., 2009; Sheldon et al., 2009). Therefore, the exogenous administration of PGF2 $\alpha$ might compensate the reduced endogenous PGF2 $\alpha$. In addition, it has been documented that administration of PGF2 $\alpha$ in postpartum cows improved reproductive performance through three difference mechanisms, including increased uterine contractility, induced luteolysis, and enhanced phagocytic activity of uterine polymorphnuclear cells (Kasimanickam et al., 2005). Moreover, administration of a PGF $2 \alpha$ analog to cows with subclinical endometritis was reported as efficacious as intrauterine infusion of cephapirin benzathine in improving reproductive performance (Kasimanickam et al., 2005). Progesterone also suppresses the immune response to lipopolysaccharides in endometrial cells in vitro
(Herath et al., 2006). Regarding the relationship between DIM and reproductive response to treatment of endometritis, the results of the present study revealed significant positive correlations between DIM and most of reproductive indices used in this experiment Table 3). In details our study showed that, the best treatment response fertility measures were recorded for endometritis positive cows detected and treated before 60 days in milk when compared to endometritis positive cows detected and treated after 60 days in milk regardless of the diagnostic and treatment protocols (Table 4). These results were supported by LeBlanc et al. (2002) who reported that cows with mucopurulent or worse uterine discharge that persisted beyond 60 DIM had a more pronounced reduction in pregnancy rate than cows with endometritis diagnosed < 60 DIM. The current study supports the likelihood that a high proportion of cows have spontaneous resolution of endometritis until at least 4 weeks postpartum. Conversely, if clinical signs associated with increased time to pregnancy are still present after 4 weeks, the condition may be more responsive to treatment. Concerning parity, the results of the current study revealed weak non-significant negative correlations between parity and all tested fertility indices (Table 3). Furthermore, the best fertility results were detected in primiparous cows compared to that observed with pleuriparous cows (Table 5). Other previous studies supported our results, Ghasemi, (2011) found negative effect of parity on response to treatment with benzathine cephapirin in cows with clinical endometritis, as disease-positive primiparous cows became pregnant 26 days sooner than pleuriparous disease-positive cows following treatment with $500 \mathrm{mg}$ benzathine cephapirin. Also related to this observation the finding in the pleuriparous cows accumulated significantly more fluid in the uterus than primiparous cows. This would suggest that the decreased effect of treatment with benzathine cephapirin in pleuriparous postpartum cows was associated with a breakdown in uterine clearance mechanisms. Furthermore, a high milk production and the parity showed associations with an excessive body condition score loss (Tsousis et al., 2009). Some studies revealed that parity is another factor that affects conception rate (Tenhagen et al., 2004; Kaufmann et al., 2009) or the chance of insemination and pregnancy (Drillich et al., 2006; Pleticha et al., 2009) while others did not (Lincke et al., 2006). Regarding the relationship between daily milk yield and reproductive response to treatment in cows affected with endometritis, the results of the present study revealed strong significant negative correlations among daily milk yield and the intervals to $1^{\text {st }}$ estrus $(-0.40)$, to $1^{\text {st }}$ service $(-.033)$, to conception (-0.58), days open (-0.57) and S/C (-0.27) as shown in table 3 . In addition, the data of the current study revealed that, cows produce more than the average daily milk recorded good fertility results when compared with that recorded for cows that 
produce less than the average daily milk (Table 6). This positive correlation between daily milk yield and fertility might be attributed to the fact that high yielding cows are subjected to good health and nutritional management policies and they are healthier than are lower yielding cows. We do not have an explanation for this finding, but it could be due to the difference in experimental design, production system, feeding regimen, and so on. In the same way, Domecq et al. (1997) concluded that, higher yielding cows were more likely to conceive than were lower yielding cows. Regarding the US picture of the uterus in cows suffered from endometritis, the results of the current study revealed that cows with Hyperechogenic endometrium recorded a significant $(\mathrm{p}<0.05)$ shorter days to $1^{\text {st }}$ estrus interval (8.4d.) compared to cows showed intra uterine luminal fluid (11.9d.) (Table 7). In the same way, it has been reported that, cows with no clinically evident signs of endometritis, but with presence of intrauterine fluid upon transrectal US have reduced reproductive performance (Kasimanickam et al., 2004; Gilbert et al., 2005). In addition, bacterial growth and impaired uterine involution have been shown to be associated with US detectable intrauterine luminal fluid accumulation. Based on this finding it was speculate that the presence of fluid in the uterus may be associated more with an impaired uterine clearance. Another theory is that uterine luminal fluid or debris in the uterine lumen may somehow dilute or inactivate benzathine cephapirin rendering it ineffective (Ghasemi, 2011). Cows with uterine luminal fluid accumulation in the uterus might benefit because of treatment with PGF $2 \alpha$ to improve uterine clearance mechanisms, or may require more than one treatment with benzathine cephapirin (Ghasemi, 2011). From these results, we can concluded that, transrectal US could be used as a reliable method for early diagnosis of endometritis in dairy cows. In addition, using a combination of IU application of benzathine cephapirin and systemic injection of synthetic PGf $2 \alpha$ is effective as a treatment protocol in endometritis.

\section{REFERENCES}

Ahmadi, M.R. and Dehghan, S.A. (2007): Evaluation of the Treatment of Repeat Breeder Dairy Cows with Uterine Lavage plus PGF2 $\alpha$, with and without Cephapirin. Turkish J. Vet. Anim. Sci. 31: 125-129.

Bicalho, R.C.; Galvao, K.N.; Guard, C.L. and Santos, J.E.P. (2008): Optimizing the accuracy of detecting a functional corpus luteum in dairy cows. Theriogenology 2008; 70:199-207.

Cheong, S.H.; Nydam, D.V.; Galvao, K.N.; Crosier, B.M.; Ricci, A.; Caixeta, L.S.; Sper, R.B.; Fraga, M. and Gilbert, R.O. (2012): Use of reagent test strips for diagnosis of endometritis in dairy cows. Theriogenology 77:858-864.
Couto, G.B.; Vaillancourt, D.H. and Lefebvre, R.C. (2013): Comparison of a leukocyte esterase test with endometrial cytology for diagnosis of subclinical endometritis in postpartum dairy cows. Theriogenology 79:103-107.

de Boer, M.W.; LeBlanc, S.J.; Dubuc, J.; Meier, S.; Heuwieser, H.; Arlt, S.; Gilbert, R.O. and McDougall, S. (2014): Invited review: Systematic review of diagnostic tests for reproductive-tract infection and inflammation in dairy cows. J. Dairy Sci. 97: 3983-3999.

Denis-Robichaud, J. and Dubuc, J. (2015): Randomized clinical trial of intrauterine cephapirin infusion in dairy cows for the treatment of purulent vaginal discharge and cytological endometritis. J. Dairy Sci. 98:6856-6864

Domecq, J.J.; Skidmore, A.L.; Lloyd, J.W. and Kaneene, J.B. (1997): Relationship between body condition scores and conception at first artificial insemination in a large dairy herd of high yielding Holstein cows. J Dairy Sci. 80:113-120.

Drillich, M.; Arlt, S.; Kersting, S.; Bergwerff, A.A.; Scherpenisse, P. and Heuwieser, W. (2006): Ceftiofur derivatives in serum, uterine tissues, cotyledons, and lochia after fetal membrane retention. J Dairy Sci 89(9): 3431-3438.

Drillich, M.; Kaufmann, T.; Raab, D.; Lenz, M. and Heuwieser, W. (2004): Comparison of new techniques for the diagnosis of chronic endometritis in dairy cattle. In: Poster abstract, the proceedings of the World Buiatrics Congress, p. 42.

Drillich, M.; Raab, D.; Wittke, M. and Heuwieser, W. (2005): Treatment of chronic endometritis in dairy cows with an intrauterine application of enzymes. A field trial. Theriogenology 63:1811-1823.

Dubuc, J.; Duffield, T.F.; Leslie, K.E.; Walton, J.S. and Leblanc, S.J. (2011): Randomized clinical trial of antibiotic and prostaglandin treatments for uterine health and reproductive performance in dairy cows. J Dairy Sci. 94: 1325-1338.

Dubuc, J.; Duffield, T.F.; Leslie, K.E.; Walton, J.S. and LeBlanc, S.J. (2010): Definitions and diagnosis of postpartum endometritis in dairy cows. J. Dairy Sci. 93:5225-5233.

Földi, J.; Kulcsár, M.; Pécsi, A.; Huyghe, B.; de Sa, C.; Lohuis, J.A.; Cox, P. and Huszenicza, G. (2006): Bacterial complications of postpartum uterine involution in cattle. Anim. Reprod. Sci. 96:265-281.

Galvão, K.N.; Frajblat, M.; Brittin, S.B.; Butler, W.R.; Guard, C.L. and Gilbert, R.O. (2009): Effect of prostaglandin F2 alpha on subclinical endometritis and fertility in dairy cows. J. Dairy Sci; 92:4906-4913. 
Ghasemi, F. (2011): Characterization of endometritis in postpartum dairy cows, MSc. Thesis, Western College of Veterinary Medicine University of Saskatchewan, Copyright Farhad Ghasemi, August 2011.

Gilbert, R.O.; Shin Sang, T.; Guard, C.L.; Hollis, E.N. and Frajblat, M. (2005): Prevalence of endometritis and its effects on reproductive performance of dairy cows. Theriogenology. 64: $1879-1888$

Giuliodori, M.J.; Magnasco, R.P.; Becu-Villalobos, D.; Lacau-Mengido, I.M.; Risco, C.A. and de la Sota, R.L. (2013): Clinical endometritis in an Argentinean herd of dairy cows: risk factors and reproductive efficiency. J. Dairy Sci. 96:210-218.

Groenendaal, H.; Galligan, D.T. and Mulder, H.A. (2004): An economic spreadsheet model to determine optimal breeding and replacement decisions for dairy cattle. J. Dairy Sci. 87: 2146-2157.

Gümen, A.; Mecitoglu, G.Y.; Keskin, A.; Karakaya, E.; Alkan, A.; Tasdemir, O. and Okut, H. (2012): The effect of interuterine cephapirin treatment after insemination on conception rate in repeat breeder dairy cows subjected to the progesterone-based Ovsynch protocol. Turk.J.Vet.Anim.Sci. 36: 622-627.

Hendricks, K.E.M.; Bartolome, J.A.; Melendez, P.; Risco, C. and Archbald, L.F. (2006): Effect of repeated administration of PGF $2 \alpha$ in the early postpartum period on the prevalence of clinical endometritis and probability of pregnancy at first insemination in lactating dairy cows. Theriogenology. 65: 1454-1464.

Herath, S.; Fischer, D.P.; Werling, D.; Williams, E.J.; Lilly, S.T.; Dobson, H.; Bryant, C.E. and Sheldon, I.M. (2006): Expression and function of Toll-like receptor 4 in the endometrial cells of the uterus. Endocrinology. 147:562-570.

Herath, S.; Lilly, S.T.; Fischer, D.P.; Williams, E.J.; Dobson, H.; Bryant, C.E. and Sheldon, I.M. (2009): Bacterial lipopolysaccharide induces an endocrine switch from prostaglandin F2alpha to prostaglandin E2 in bovine endometrium. Endocrinology 150: 1912-1920.

Huzzey, J.M.; Veira, D.M.; Weary, D.M. and von Keyserlingk, M.A. (2007): Prepartum behavior and dry matter intake identify dairy cows at risk for metritis. J. Dairy Sci. 90: 3220-3233.

Kasimanickam, R.; Duffield, T.F.; Foster, R.A.; Gartley, C.J.; Leslie, K.E.; Walton, J.S. and Johnson, W.H. (2004): Endometrial cytology and ultrasonography for the detection of subclinical endometritis in postpartum dairy cows. Theriogenology. 62: 9-23.

Kasimanickam, R.; Duffield, T.F.; Foster, R.A.; Gartley, C.J.; Leslie, K.E.; Walton J.S. and Johnson W.H. (2005): The effect of a single administration of cephapirin or cloprostenol on the reproductive performance of dairy cows with subclinical endometritis. Theriogenology. 63:818-830.

Kaufmann, T.B.; Drillich, M.; Tenhagen, B.A.; Forderung, D. and Heuwieser, W. (2009): Prevalence of bovine subclinical endometritis $4 \mathrm{~h}$ after insemination and its effects on first service conception rate. Theriogenology. 71:385-391.

LeBlanc, S.J. (2008): Postpartum uterine disease and dairy herd reproductive performance: A review. The vet. J. 176: 102-114.

LeBlanc, S.J.; Duffield, T.F.; Leslie, K.E.; Keefe, G.P.; Walton, J.S. and Johnson, W.H. (2002): Defining and diagnosing clinical endometritis and its impact on reproductive performance in dairy cows. J. Dairy Sci. 85: 2223-2236.

Lefebvre, R.C. and Stock, A.E. (2012): Therapeutic efficiency of antibiotics and prostaglandin F2 in postpartum dairy cows with clinical endometritis: an evidence-based evaluation. Vet Clin North Am Food Anim. Pract. 28:7996.

Lewis, G.S. (2004): Steroidal regulation of uterine immune defences. Anim. Reprod. Sci. 82/83: 281-294.

Lincke, A.; Drillich, M. and Heuwieser, W. (2006): Subclinical endometritis in dairy cattle and its effect on reproductive performance - a review on recent publications. Berl. Münch. tierarztl. Wschrift 120: 245-250.

Lincke, A.; Kersting, S. and Drillich, M. (2005): Treatment of subclinical endometritis in dairy cows with proteolytic enzymes or prostaglandin F2alpha and its effect on reproductive performance. In: 6th Middle European buiatrics congress. Krakow, Polen,: 320-324.

McDougall, S.; Macaulay, $R$. and Compton, $C$. (2007): Association between endometritis diagnosis using a novel intravaginal device and reproductive performance in dairy cattle. Anim. Reprod. Sci. 99:9-23.

NRC (2001): Nutrient Requirements of Dairy Cattle. 7th rev. ed. National Academies Press, Washington, DC.

Palmer, C.W. (2008): Postpartum endometritis: Current concepts in diagnosis and treatment. 29th World Vet. Congress: 241-250.

Pleticha, S.; Drillich, M. and Heuwieser, W. (2009): Evaluation of the Metricheck device and the gloved hand for the diagnosis of clinical endometritis in dairy cows. J. Dairy Sci. 92: 5429-5435.

Priest, N.V.; McDougall, S.; Burke, C.R.; Roche, J.R.; Mitchell, M.; McLeod, K.L.; Greenwood, S.L. and Meier, S. (2013): The responsiveness of subclinical endometritis to a nonsteroidal antiinflammatory drug in pasture grazed dairy cows. J. Dairy Sci. 96:4323-4332. 
Runciman, D.J.; Anderson, G.A.; Malmo, J. and Davis, G.M. (2008): Effect of intrauterine treatment with cephapirin on the reproductive of seasonally calving dairy cows at risk of endometritis following periparturient disease. Aust. Vet. J. 86:250-258.

Runciman, D.J.; Andersonb, G.A. and Malmoc, J. (2009): Comparison of two methods of detecting purulent vaginal discharge in postpartum dairy cows and effect of intrauterine cephapirin on reproductive performance. Aust. Vet. J. 87:369-378

Sheldon, I.M. and Dobson, H. (2004): Postpartum uterine health in cattle. Anim. Reprod. Sci. 8283:295-306.

Sheldon, I.M.; Lewis, G.S.; LeBlanc, S. and Gilbert, R.O. (2006): Defining postpartum uterine disease in cattle. Theriogenology. 65:15161530.

Sheldon, I.M.; Price, S.B.; Cronin, J.; Gilbert, R.O. and Gadsby, J.E. (2009): Mechanisms of infertility associated with clinical and subclinical endometritis in high producing dairy cattle. Reprod. Domest. Anim. 44 Suppl 3: $1-9$.

Shephard, R.W. (2005): The sensitivity and specificity of single manual examination tests for detection of corpora lutea in the ovaries of non-cycling cows. Aust. Vet. J. 83:572-576.

SPSS, (2013): Statistics for windows version 22.0. Armonk, NY: IBM corp.

Tenhagen, B.A.; Surholt, R.; Wittke, M.; Vogel, C.; Drillich, M. and Heuwieser, W. (2004): Use of Ovsynch in dairy herds-differences between primiparous and pleuriparous cows. Anim. Reprod. Sci. 81:1-11.

Tsousis, G.; Sharifi, R. and Hoedemaker, M. (2009): Associations between the clinical signs of chronic endometritis with ovarian cysts and body condition loss in German Holstein Friesian cows. J. Vet. Sci. Dec.10:337-341.

Weems, C.W.; Weems, Y.S. and Randel, R.D. (2006): Prostaglandins and reproduction in female farm animals. Vet. J. 171: 206-228.

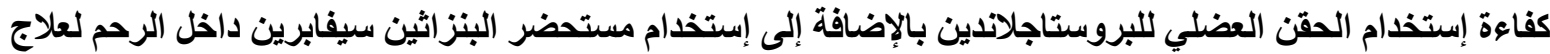

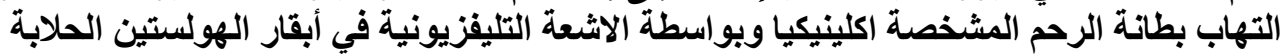

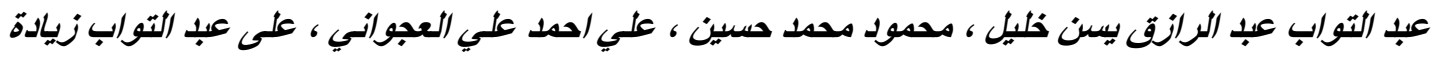

Email: yassyn999@yahoo.com Assiut University web-site: www.aun.edu.eg

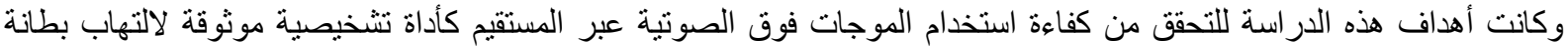

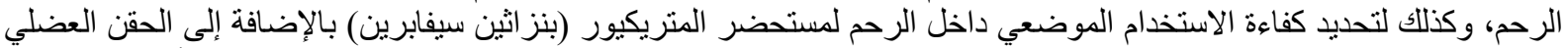

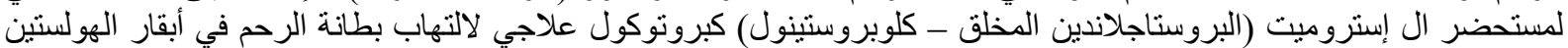

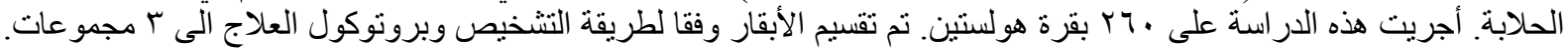

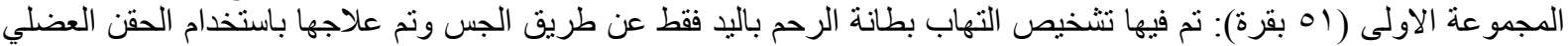

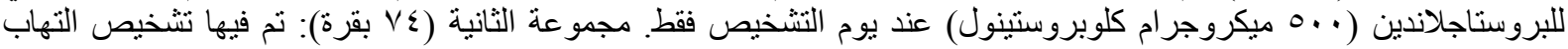

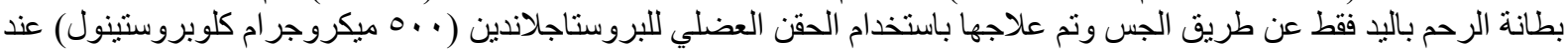

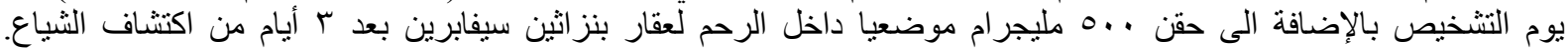

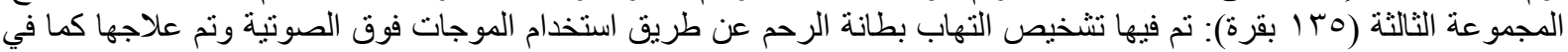

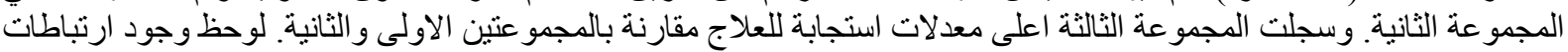

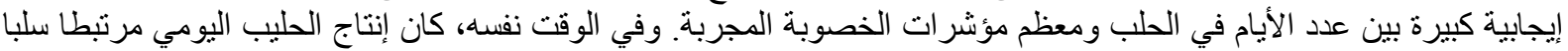

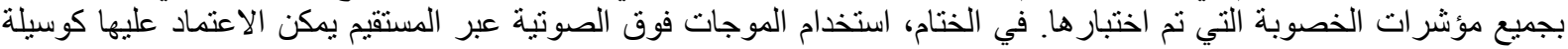

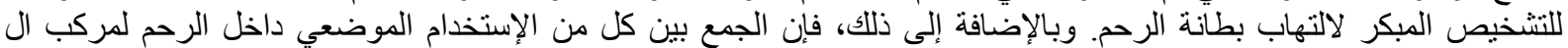

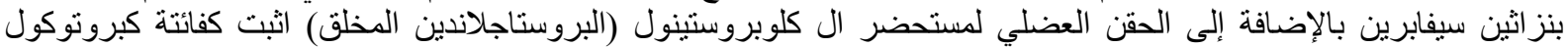
علاجي فعال لالتهاب بطانة الرحم في الأبقار الحلابة.
\end{abstract}

